\title{
Implementasi Pendidikan Karakter Melalui Program Tahfidz Alquran
}

\author{
Valentina Marisa ${ }^{1}$ Indah Muliati $^{2}$ \\ Jurusan Ilmu Agama Islam, Fakultas Ilmu Sosial, Universitas Negeri Padang, Indonesia ${ }^{1,2}$ \\ valentinamarisa123@gmail.com ${ }^{1}$ indahmuliati1979@gmail.com²
}

\begin{abstract}
This research is character education is still not optimal in schools and reality is there are still much crimes both in electronic media crimes and printed media crimes. Its make students forget to back recite al-Qur'an again. The research objective was conducted to determine the implementation of character education through the tahfidz. al-Qur'an program, to include what character values are embedded in the program, to find out what values are implanted in the tahfidz al-Qur'an program at the Laboratory Development Junior High School. UNP. This research is a descriptive qualitative research by conducting interviews, observation, and documentation. The data that has been collected can be used to describe the situation in the field, this data making from writing data. The results of this study indicate that character education through the tahfidz al-Qur'an program at the UNP Laboratory Development Junior High School has been going well in shaping the character of the spirit of the students' Qur'ani. Its implementation includes learning tahfidz al-Qur'an and internalizing character values. The character education through the tahfidz al-Qur'an program students appear to have the character of being honest, confident, hardworking, appreciating with time, having self-respect, and being independent. This can be seen in the morals of students during learning and outside learning has a positive impact.
\end{abstract}

Keywords: Character Education, Character Values, Tahfidz Program

\section{Pendahuluan}

Menurut Muchsin (2019) pendidikan merupakan usaha sadar serta terencana yang diwujudkan dalam suasana belajar melalui proses pembelajaran supaya peserta didik secara aktif meningkatkan kemampuan dirinya agar mempunyai jiwa spiritual keagamaan, pengendalian diri, keceradasan, akhlak mulia, dan keahlian. Salah satu bagian penting yang diperoleh terkait pendidikan merupakan menanamkan nilai karakter. Zubaidi (2012) mengemukakan bahwa karakter ialah mustika hidup yang membedakan manusia dengan hewan. Karena manusia tanpa karakter merupakan manusia yang menyamai hewan (Doni, 2010). Orang-orang yang berkepribadian baik dan kuat secara individual ataupun sosial yakni mereka yang mempunyai moral, akhlak serta budi pekerti yang baik. Mengingat karakter itu sangat penting, maka lembaga pendidikan mempunyai tanggung jawab menanamkannya dalam proses pembelajaran.

Pengoptimalan penguatan nilai-nilai karakter tidak hanya didapatkan pada aktivitas belajar mengajar sesuai kurikulum serta karakter yang tercantum dalam KI. 1 dan KI. 2. Namun, didukung pula dengan program tertentu dalam menguatkan karakter serta pengembangan kemampuan peserta didik. Sehubungan dengan hal tersebut, di SMP Pembangunan Laboratorium UNP dengan terdapatnya program tahfidz, diharapkan siswa dapat dekat dengan Al-Qur'an sehingga dengan mudah dapat menanamkan nilai karakter dalam proses pendidikan, serta terjadinya kepribadian siswa yang beriman, bertakwa dan berakhlak mulia. 
Berdasarkan pada hasil wawancara dengan Bapak Nasri B, S. Pd. I pada tanggal 18 maret 2021 di ruang majelis guru diperoleh informasi bahwa masih terdapat sebagian siswa yang kurang disiplin serta kurang terdapatnya rasa tanggung jawab saat diberi tugas rumah, kurang sopan terhadap guru, masih banyak yang tidak mengikuti ketentuan sekolah semacam tidak boleh terlambat tiba ke sekolah, serta mengusik temannya yang lagi belajar dan akhirnya berkelahi. Maka dengan terdapatnya pembelajaran tahfidz al-Qur'an bisa menjadi wadah sekolah untuk menanamkan nilainilai karakter yang baik kepada siswa, sebab siswa yang dekat dengan al-Qur'an tentu mempunyai kepribadian yang baik. Berdasarkan pada dari paparan di atas, penulis termotivasi untuk mengadakan penelitian lebih lanjut menimpa penguatan pendidikan karakter dengan judul "Implementasi Pendidikan Karakter Melalui Program Tahfidz AlQur'an"

\section{Tinjauan Pustaka}

\section{Tinjauan Tentang Pendidikan Karakter}

\section{a. Karakter}

Karakter merupakan sifat, watak ataupun hal-hal yang memanglah sangat mendasar yang terdapat pada diri seseorang yang membedakan dirinya dengan orang lain. Seseorang bisa dikatakan berkarakter bila sukses meresap nilai serta kepercayaan yang dihendaki warga dan digunakan dalam melaksanakan tugasnya selaku pendidik (Furqon, 2010).

\section{b. Pendidikan Karakter}

Pendidikan karakter merupakan proses menanamkan nilai-nilai kepribadian, baik sifatnya individual personal ataupun social (Furqon, 2010). Bertujuan untuk tingkatkan kualitas serta hasil proses pembelajaran baik dalam proses pendidikan ataupun diluar pendidikan yang menuju pada penanaman nilai- nilai kepribadian baik serta akhlak mulia peserta didik secara utuh, merata, serta sesuai dengan kompetensi lulusan pembelajaran pada tiap jenjang pendidikan (Mulyasa, 2013).

\section{c. Metode Penanaman Nilai Karakter}

\section{1) Metode Keteladanan}

Metode keteladanan merupakan perkataan maupun perbuatan yang dilakukan oleh guru hendak jadi panutan untuk anak didiknya. Sebab siswa di sekolah lebih banyak berhubungan dengan gurunya. Siswa menyangka kalau di area sekolah guru yang wajib dihormati serta ditiru. Sehingga ketika guru berperan jujur, berakhlak mulia, berani, serta menjauhkan diri dari perihal yang dilarang agama maka siswa hendak meniru hal yang sama.

\section{2) Metode Pembiasaan}

Metode yang mengarahkan siswa buat melakukan suatu yang baik secara berulang- ulang yang kesimpulannya jadi suatu kebiasaan.

\section{3) Metode Motivasi}

Metode ini sangat jitu dalam membagikan stimulus kepada siswa agar meningkatkan semangat dalam belajar serta potensinya. Motivasi bisa membagikan akibat positif dalam pertumbuhan mental, moral, serta kepribadian (Helmawati, 2014).

\section{4) Metode Penghargaan dan Hukuman}

Metode reward and punishment bisa membentuk kepribadian siswa. Sebab pada dasarnya siswa mau diberi penghargaan serta dihargai. Wujud penghargaan atas sikap baik yang dilakukan supaya membuat siswa lebih termotivasi dan percaya diri. Sebaliknya punishment ialah wujud konsekuensi atas sikap yang dilakukan siswa yang tidak mengasyikkan (Azis, 2016). 


\section{d. Tinjauan Tentang Program Tahfidz Al-Qur'an}

\section{a. Pengertian Program Tahfidz Al-Qur'an}

Program tahfidz al-Qur'an ialah salah satu penguatan pembelajaran karakter dibidang keagamaan. Prinsip-prinsip dasar dalam pembelajaran siswa salah satunya merupakan dengan ikatan rohani antara lain mengikat anak dengan al-Qur'an. Ikatan rohani merupakan ikatan jiwa dengan kejernihan serta sinar keimanan serta keikhlasan jiwanya begitu luhur dalam situasi yang penuh kesucian. Sebab al-Qur'an selaku pedoman hidup umat islam (Nasih, 2006)

Tahfidz al-Qur'an ialah proses buat memelihara, melindungi serta melindungi al-Qur'an dalam ingatan buat menaikkan keimanan serta ketakwaan kepada Allah swt. sekalian supaya tidak terjalin pergantian serta pemalsuan (Nasih, 2006).

\section{b. Keutamaan Membaca dan Menghafal Al-Qur'an}

1. Allah hendak tingkatkan derajat serta membagikan peran yang terhormat, dan senantiasa dalam rahmat Allah. Hendak namun, perihal tersebut jangan dijadikan selaku tujuan utama dalam menghafal sebab tujuan menghafal al-Qur'an untuk menemukan ridho Allah.

2. Orang yang hafal al-Qur'an tercantum dalam sebaik-baik umat.

3. Menemukan syafaat di hari kiamat

4. Menemukan kebaikan berlipat ganda.

5. Mendapatkan tingkatan surga yang besar.

\section{c. Metode Pembelajaran Tahfidz Al-Qur'an}

\section{Metode Juz' i}

Metode juz'i merupakan menghafal secara berangsur-angsur ataupun sebagian demi sebagian serta menghubungkan antar bagian ayat satu dengan ayat yang lain dalam satu kesatuan modul yang dihafal. Berarti pada metode ini siswa mencampurkan hafalan yang telah dihafal tadinya dengan hafalan ayat yang baru. Oleh karena itu, wajib banyak-banyak di muraja'ah (Umar, 2017)

2. Metode Takrir (mengulang)

Metode takrir ialah metode ngulang hafalan yang sudah diperdengarkan kepada ustadz ataupun pembimbing tahfidz, yang guna utamanya untuk melindungi supaya ayat yang telah dihafal tidak lupa (Umar, 2017)

3. Metode Setor

Metode setor merupakan memperdengarkan hafalan-hafalan baru kepada pembimbing ataupun ustadz. Metode ini wajib dilaksanakan oleh siswa supaya hafalan siswa meningkat serta sesuai dengan sasaran yang telah didetetapkan oleh sekolah. Dan melalui metode ini teks siswa hendak jadi lebih baik. Sebab guru hendak memperdengarkan teks siswa satu persatu.

4. Metode Tes

Metode uji merupakan metode yang digunakan oleh guru untuk menguji totalitas hafalan siswa sepanjang satu semester. Metode ini dengan menekankan pada materi ketepatan makhorijul huruf serta tajwid. Dengan demikian, metode ini digunakan buat mengenali ketercapaian materi yang sudah dipelajari (Umar, 2017). 


\section{Metodologi Penelitian}

Metode penelitian yang peneliti gunakan merupakan kualitatif deskriptif yaitu dengan melaksanakan wawancara, observasi, serta dokumentasi. Sehingga didapatkan informasi yang digunakan untuk menggambarkan suasana di lapangan dalam bentuk tulisan. Peneliti selaku instrumen kunci (Sugiyono, 2016: 15) menggambarkan kenyataan bersumber pada informasi yang terdapat di lapangan pada obyek yang alamiah tanpa mengganti ataupun memanipulasi informasi sehingga pada penelitian kualitatif untuk menguji keabsahan informasi dengan memakai triangulasi. Triangulasi dimaksudkan untuk memastikan informasi dari bermacam sumber dengan bermacam metode, serta bermacam waktu.( Sugiyono, 2016: 372).

\section{Hasil Penelitian Dan Pembahasan}

Informasi yang disajikan disini ialah hasil penelitian lapangan dengan teknikteknik penggalian informasi yang sudah diresmikan ialah dengan wawancara, observasi serta dokumentasi.

\section{Penerapan Pendidikan Karakter Melalui Program Tahfidz Al-Qur'an di SMP Pembangunan Laboratorium UNP}

Pembelajaran tahfidz al-Qur'an di SMP Pembangunan Laboratorium UNP dilaksanakan setiap hari dengan alokasi waktu 40 menit. Waktu yang relatif pendek dalam suatu pendidikan. Berdasarkan wawancara pada 12 Oktober 2020 di ruang majelis guru dengan ibu Nanik Pratiwi sebagai wakil kurikulum didapatkan informasi bahwa program tahfidz al-Qur'an di SMP Pembangunan Laboratorium UNP pada dasarnya masuk dalam aktivitas ekstrakurikuler. Tetapi, penerapannya di SMP Pembangunan Laboratorium UNP selaku aktivitas intrakurikuler serta program harus yang jadi muatan kurikulum karakteristik khas sekolah yang wajib diiringi oleh seluruh jenjang kelas dari kelas VII- IX yang dilaksanakan setiap minggu sekali.

Berdasarkan pada hasil wawancara dengan kepala sekolah bertepatan pada tanggal 12 maret 2021 diruang kepala sekolah diperoleh informasi program tahfidz alQur'an bertujuan untuk mendekatkan peserta didik dengan al-Qur'an dan bukan hanya bisa meningkatkan keahlian membaca serta menghafal al-Qur'an secara mudah sesuai dengan kaidah ilmu tajwid maka penerapannya wajib menekankan dalam pengembangan nilai-nilai karakter.

Pembelajaran karakter melalui program tahfidz al-Qur'an tidak lepas dari penerapan pendidikan tahfidz al-Qur'an itu sendiri. Sebab pendidikan umumnya identik terpaut dengan materi yang di informasikan oleh guru. Maka penerapan program tahfidz al-Qur'an di SMP Pembangunan Laboratorium UNP semacam penerapan pendidikan pada biasanya dengan memakai metode dalam pembelajarannya semacam metode muraja'ah yaitu tata cara mengulang hafalan yang sudah diperdengarkan kepada ustadz ataupun pembimbing tahfidz. Metode juz' i merupakan tata cara menghafal secara berangsur-angsur ataupun sebagian demi sebagian serta menghubungkan antar bagian ayat satu dengan ayat yang lain dalam satu kesatuan surat yang dihafal. Metode setor merupakan memperdengarkan hafalan-hafalan baru kepada pembimbing ataupun ustadz. Tata cara ini wajib dilaksanakan oleh siswa biar hafalan siswa meningkat serta cocok dengan sasaran yang telah didetetapkan oleh sekolah. Dan lewat tata cara ini teks siswa hendak jadi lebih baik. Sebab guru hendak memperdengarkan teks siswa satu persatu.

Berdasarkan wawancara pada tanggal 16 maret 2021 diruang majelis guru dengan ibu Ostavia selaku guru tahfidz kelas VIII didapatkan informasi bahwa dalam pembelajaran tahfidz al-Qur'an di SMP Pembangunan Laboratorium UNP memiliki 
standar materi yang wajib diterima oleh siswa buat tiap jenjang kelas. Standar ini telah tertulis dalam kurikulum sekolah selaku wujud pengembangan diri siswa. Standar kurikulum tersebut telah dibangun dalam suatu modul yang dijadikan pedoman guru serta siswa. Materi tersebut berkenaan dengan hafalan kelas VII materi yang diajarkan oleh bapak Ibnu Wardana adalah al-Qur'an juz 30, kelas VIII diajarkan oleh ibu Ostavia adalah al-Qur'an juz 1 dan kelas IX diajarkan oleh bapak Efendi adalah al-Qur'an juz 29. Sehingga ketika nanti tamat dari sekolah siswa telah menghafalkan 3 juz al-Qur'an.

Langkah- langkah pembelajaran karakter lewat program tahfidz al-Qur'an. Saat sebelum mengawali pendidikan guru senantiasa mengucapkan salam serta mengakihiri dengan doa. Setelah itu menunjuk salah satu siswa buat mempersiapkan di depan kelas selaku penanaman kepribadian percaya diri. Diilanjutkan dengan siswa bersalaman dengan guru selaku wujud pembiasaan buat menghormati guru. Guru mempraktikkan pendidikan program tahfidz yang sesuai dengan pedoman program tahfidz al-Qur'an. Guru memakai metode muraja'ah pada dikala pembiasaan pagi, bin nadhar dikala jam mengaji, serta tata cara setor. Guru menanamkan kepribadian pada peserta didik memakai tata cara yang bermacam-macam semacam tata cara keteladanan, pembiasaan, motivasi, serta reward and punishment.

Pembiasaan yang dilaksanakan guru merupakan metode yang mengarahkan siswa untuk melakukan suatu yang baik secara berulang- ulang yang kesimpulannya jadi suatu kebiasaansaat sebelum pembelajaran maupum sepanjang pembelajaran. Metode keteladanan dilaksanakan guru lewat perkataan, gerak gerik serta tingkah laku guru. Metode motivasi dilaksanakan guru buat membagikan stimulus kepada peserta didik biar bisa menggapai sasaran hafalan yang telah didetetapkan oleh sekolah. Reward diberikan oleh guru kepada siswa yang bisa menggapai sasaran. Guru sepanjang pendidikan menampilkan contoh yang baik kepada peserta didik.

\section{Nilai-Nilai Karakter yang ditanamkan Melalui Program Tahfidz Al-Qur an}

a. Jujur

Jujur ialah suatu watak yang menyatakan kesesuaian perilaku antara perkataan yang diucapkan dengan perbuatan yang dicoba oleh seorang. Jadi, seorang bisa dikatakan jujur bila dia mengucapkan suatu yang cocok dengan sesungguhnya serta diiringi aksi yang sepatutnya. Pada kepribadian jujur guru menguatkan semacam mengecek kesesuaian atas hafalan peserta didik dengan bertanya pada siswa tentang hafalannya. Perihal tersebut diperkuat oleh guru dengan memandang antara kesesuaian catatan yang diucapkan peserta didik dengan catatan buku tahfidz. Setelah itu guru hendak menasihati siswa bila siswa berbohong tentang hafalannya serta memohon siswa buat kembali ke bangkunya serta menghafal cocok hafalannya serta melaksanakan setoran.

Perihal ini dicoba guru selaku wujud punishment biar siswa terbiasa untuk mengatakan jujur dalam perihal sekecil apapun serta tidak mengatakan bohong. Penguatan pembelajaran karakter jujur didukung pula dengan terdapatnya catatan surah juz yang dihafalkan cocok tingkatan kelas tiap-tiap yang dibaca siswa kala sholat dengan dicatat sendiri yang terletak dalam buku program tahfidz al-Qur'an. Wali murid serta wali kelas wajib menandatangani buku pedoman siswa selaku wujud pembiasaan siswa buat berperilaku jujur dengan orang tua ataupun guru yang pada kesimpulannya siswa hendak terbiasa buat mengatakan serta berperilaku jujur pada orang lain.

b. Percaya diri

Percaya diri ialah sesuatu kondisi dimana seorang mengakui hendak keahlian pribadinya dalam melaksanakan ataupun menuntaskan suatu. Rasa percaya diri tersebut dinilai bersumber pada komentar individu serta oleh diri sendiri. Pertama-tama guru tidak memanggil siswa buat melakukan setoran hafalan. Perihal ini biar siswa 
secara suka rela buat menyetorkan hafalannya. Setelah itu guru memohon siswa buat menyetorkan secara lantang serta keras, biar siswa yang lain pula turut menyimak. Sehingga lama kelamaan siswa jadi yakin diri buat menyetorkan hafalan tanpa wajib dipanggil terlebih dulu. Siswa menampilkan perilaku suka rela dalam melaksanakan setoran tanpa wajib diinstruksi terlebih dulu dari guru. Guru menguatkan nilai percaya diri dengan mengadakan festival tahfidz selaku ajang berkompetisi serta memupuk rasa berani serta yakin diri siswa buat menghafalkan di depan kelas.

\section{c. Pekerja keras}

Pekerja keras ialah aktivitas yang dicoba secara bersungguh-sungguh tanpa memahami kata letih, pantang menyerah serta tidak hendak menyudahi saat sebelum sasaran ataupun tujuan yanng dipunyai tercapai. Guru mengharuskan untuk siswa buat melaksanakan setoran tiap minggunya minimun 5 ayat untuk memenuhi sasaran hafalan yang telah diresmikan guna menguatkan karakter pekerja keras siswa. Dan untuk siswa yang masih belum mudah hafalannya, hingga siswa hendak dimohon buat terus menerus mengulangi hafalannya hingga benar.

Guru menguatkan dengan melaksanakan muraja'ah pagi biar siswa lancar serta tidak gampang lupa dengan hafalannya. Siswa sepanjang setoran pula nampak semangat dalam mengulangi hafalannya hingga mudah. Perihal ini diperkuat oleh guru dengan mengharuskan siswa buat melaksanakan setoran tiap minggunya. Sehingga siswa hendak senantiasa muraja'ah hafalannya buat menggapai sasaran hafalan cocok jenjang kelas yang wajib diselesaikan.

d. Menghargai waktu

Menghargai waktu merupakan kala seorang memakai waktu yang dimiliki buat melaksanakan hal-hal yang berguna serta semaksimal bisa jadi sesuai dengan sasaran yang dimilikinya. Dalam 1 jam pelajaran program tahfidz al-Qur'an nampak siswa memakai waktu dengan efisien. Perihal ini dibuktikan dengan siswa senantiasa mencermati arahan dari guru, tidak jai. Siswa terlihat fokus dalam pembelajaran untuk mengejar sasaran hafalan, tidak hanya itu peserta didik menuntaskan hafalannya dengan tepat waktu.

Guru mengharuskan siswa untuk melakukan setoran hafalan tiap minggunya, untuk siswa yang tidak melakukan setoran maka siswa bisa pulang terakhir sampai melakukan setoran. Perihal ini bertujuan biar kala dirumah siswa pula mengosongkan waktunya buat membaca serta menghafalkan hafalannya. Sebab dengan diwajibannya siswa buat setoran tiap minggunya membuat siswa wajib memakai waktu sebaik-baiknya buat penuhi sasaran hafalan. Tidak cuma itu, guru pula menyesuikan siswa buat disiplin dalam muraja' ah pagi di kelas serta bila siswa terlambat hingga siswa hendak dimohon buat maju serta berdiri di depan kelas dengan senantiasa menjajaki muraja' ah hingga berakhir.

Bila siswa terlambat hingga hendak dimasukkan dalam buku catatan sikap siswa yang wajib dikenal orang tua siswa. Sehingga hukuman dapat membagikan dampak jera pada siswa buat tidak mengulangi perihal yang sama. Punishment tersebut dapat diberikan selaku guna dampak jera pada siswa, tanpa wajib memukul siswa biar tidak membagikan dampak trauma pada siswa. Terlebih siswa SMP yang pada dasarnya masih muda mental serta emosinya yang belum matang masih banyak memerlukan tutorial serta arahan dari guru.

\section{e. Mempunyai harga diri}

Harga diri ialah selaku evaluasi orang terhadap dirinya sendiri, serta pula selaku pemikiran totalitas dari orang tentang dirinya sendiri. Siswa nampak sopan santun serta pula nampak tertib mengantri buat melaksanakan setoran. Perihal ini selaku wujud buat menghargai sesama orang lain. Guru menguatkan kepribadian dengan 
membagikan penghargaan pada dirinya atas suatu yang sudah dicapai dengan memupuk saya saing. Sehingga siswa hendak menghargai serta tingkatkan prestasinya.

Guru menguatkan kepribadian ini dengan memupuk budaya antri pada siswa serta senantiasa memupuk energi saing antar siswa. Perihal ini biar siswa memiliki jiwa kompetitif. Misalnya siswa dalam kelas VIII guru membagikan penghargaan untuk siswa yang menggapai sasaran hafalan tercepat dari pada sahabatnya. Sehingga siswa termotivasi buat menuntaskan sasaran hafalannya. Jika seorang anak berbuat terpuji, sebaiknya diberikan pujian serta sanjungan dan menemukan ganjaran, sehingga hendak merasakan rasa suka dalam dirinya. Terlebih untuk anak umur operasional konkrit senantiasa memerlukan pengakuan serta penghargaan orang lain. Sebab pada dasarnya anak lebih bahagia bila dihargai atas kemampuannya ataupun prestasinya. Sehingga siswa akan menjadi lebih semangat dalam meningkatkan prestasinya.

f. Mandiri

Mandiri merupakan sesuatu perilaku buat tidak menggantungkan keputusan kepada orang lain dalam menuntaskan sesuatu tugas serta kasus yang dapat dituntaskan oleh dirinya sendiri. Guru menguatkan kepribadian mandiri dengan memohon siswa maju satu persatu dalam satu minggu buat melakukan setoran. Sehingga disela-sela waktu rehat siswa terlihat melaksanakan hafalan sendiri tanpa dorongan guru. Tidak hanya itu, siswa terlihat masih terlihat saling menyimak hafalan dengan temannya sepanjang masih mengantri buat melaksanakan setoran.

Untuk menguatkan karakter mandiri guru membiasakan siswa untuk melaksanakan setoran hafalan secara mandiri dengan maju satu persatu sekalian secara suka rela tanpa wajib memanggil nama-nama siswa terlebih dulu. Perihal ini pula yang membuat peserta didik senantiasa melaksanakan hafalan secara mandiri di rumah. Sebagaimana hasil wawancara dengan peserta didik pada 14 maret 2021 untuk memenuhi sasaran hafalan siswa mengulang-ngulang hafalan di rumah sendiri tanpa bantuan orang tua serta masih belajar lewat pembelajaran di TPQ dan melaksanakan hafalan disela-sela waktu rehat.

Sejalan dengan teori habituasi (habituition) yang berkata kalau untuk menanamkan kepribadian pada siswa butuh terdapatnya pembiasaan serta pengalaman secara langsung. Sama halnya di SMP Pembangunan Laboratorium UNP untuk menanamkan siswa mandiri dengan pembiasaan-pembiasaan yang diperoleh siswa secara langsung.

Dengan demikian, bisa disimpulkan kalau penguatan karakter mandiri di SMP Pembangunan Laboratorium UNP telah diperkuat lewat pembiasaan dalam menghafal secara sukarela sekalian satu persatu, kewajiban menghafal tiap minggu sekali, serta pembiasaan untuk menyimak hafakan dengan sahabat sebaya. Perihal seperti itu yang membuat siswa menggunakan waktu rehat buat mengulangulang hafalan secara mandiri.

\section{Simpulan}

Bersumber pada penelitian implementasi pembelajaran karakter melalui program tahfidz al-Qur'an SMP Pembangunan Laboratorium UNP tahun ajaran 2020/ 2021 bisa disimpulkan sebagai berikut:

Pembelajaran kepribadian lewat program tahfidz al-Qur'an di SMP Pembangunan Laboratorium UNP berjalan dengan baik. Penerapannya dengan pemberian materi yang berbeda tiap tingkatan kelas wajib dihafal siswa dengan tata cara muroja'ah, bin nadhar, serta setoran dalam tingkatkan keahlian membaca serta menghafal al- Qur' an. Sekalian dalam internalisasi nilai kepribadian siswa dengan tata 
cara pembiasaan pada siswa buat berperilaku jujur terpaut dengan hafalannya, percaya diri ketika wajib menyetorkan hafalan di depan kelas, pekerja keras dengan metode mengulang-ulang hafalan hingga mudah, sehingga menghargai waktu dengan memakai waktu dengan efektif bisa jadi sepanjang pembelajaran, mandiri dalam melaksanakan hafalan sendiri waktu rehat, mempunyai harga diri dengan membagikan penghargaan atas prestasi yang dicapai siswa. Kepribadian tersebut nampak sepanjang pendidikan program tahfidz al-Qur'an serta diluar pendidikan program tahfidz.

\section{Referensi}

Azis, Reward And Punhisment sebagai motivasi Pembelajaran( Persepektif Barat serta Islam), “ Cendekia”,( Vol. 14, Nomor. 2, tahun 2016), hlm. 377- 378.

Helmawati,( 2014). Pembelajaran Keluarga Teoritis serta Instan, Bandung: Anak muda Rosdakarya Offset.

Hidayatullah, M Furqan,( 2010). Pendidikan Karakter: Membangun Peradaban Bangsa, Surakarta: Yumna Pusaka.

Koesoema, Doni,( 2010). Pembelajaran Kepribadian Strategi Mendidik Anak di Era Global, Jakarta: Grasindo.

Muchsin, B dan Abdul Wahid,( 2009). Pembelajaran Islam Kontemporer. Bandung: PT Refika Aditama.

Mulyasa,( 2013). Manajemen Pembelajaran Kepribadian, Jakarta: Bumi Aksara.

Nasih, Abdullah Ulwan,( 2006). Ensiklopedia Pembelajaran Akhlak Mulia Panduan Mendidik Anak Bagi Tata cara Islam jil. 9, Jakarta: PT Ikrar Mandiriabadi.

Sugiyono,( 2016). Tata cara Riset Pembelajaran Pendekatan Kuantitatif, kualitatif, serta R\&amp;D, Bandung: Alfabeta.

Umar,“ Implementasi Pendidikan Tahfidz Al- Qur' an Di SMP Lukman Hakim”, Harian Pembelajaran Islam,( Vol. 6, Nomor. 1, tahun 2017), hlm. 8. 3

Zubaedi,( 2012). Desain Pembelajaran Kepribadian Konsepsi Serta Aplikasinya Dalam Dunia Pembelajaran. Jakarta: Kencana. 